\section{PENINGKATAN DIGITAL LITERASI TERHADAP UJARAN KEBENCIAN DI MEDIA SOSIAL MELALUI PROGRAM "ROOM OF LAW" BAGI SISWA SEKOLAH MENENGAH ATAS DI KOTA SERANG}

\author{
Fuqoha $^{1}$, Ananda Putri Anggraini², Nabila Dea \\ Apipah $^{3}$
}

Program Studi Ilmu Hukum, Universitas Serang Raya, Serang

*Corresponding author

Email : fuqoha23@gmail.com

\title{
Abstraksi
}

Tujuan dari kegiatan pengabdian masyarakat ini adalah memberikan pendidikan dan pemahaman kepada siswa-sisiwi sekolah terhadap potensi dan bahaya ujaran kebencian melalui media sosial. Diharapkan melalui kegiatan ini mendorong siswa sekolah untuk menghindari dan memerangi perilaku ujaran kebencian khsusunya di media sosial. Metode kegiatan adalah Participatory Learning and Action yang menekankan pada sosialisasi, diskusi serta pelatihan dan pendidikan digital literasi. Hasil kegiatan Room of Law dalam pengabdian ini menunjukan masih lemahnya pengetahuan siswa sekolah terhadap ujaran kebencian di media sosial dan ancaman hukuman yang diakibatkan dari perbuatan ujaran kebencian. Pengabdian ini masih terus dilaksanakan guna menciptakan Agent Of Against Hate Speech melalui pelatihan dan pendidikan bagi siswa-siswi sekolah (Training of Train).

Kata kunci : Peningkatan Digital Literasi, Pelatihan dan Pendidikan Agen Perlawanan Ujaran Kebencian.

\begin{abstract}
The purpose of this community service activity is to provide education and understanding to students and the school towards the potential and dangers of hate speech through social media. It is hoped that through this activity encourage school students to avoid and combat the behavior of speech utterances especially on social media. The activity method is Participatory Learning and Action which emphasizes socialization, discussion and training and digital literacy education. The results of the "Room of Law" activities in this service show that students' knowledge is still weak about the utterances of hate in social media and the threat of punishment resulting from acts of hate speech. This service is still being carried out to create Agent of Against Hate Speech through training and education for Training of Train students.

Keywords: Digital Improvement of Literacy, Training and Education of Agents of Against Hate Agencies
\end{abstract}




\section{PENDAHULUAN}

Perkembangan teknologi informasi dalam pergaulan hidup bermasyarakat menciptakan pola komunikasi yang beragam serta memberikan kemudahan dalam bersosialisasi antarmasyarakat. Pola komunikasi yang terbangun seiring kemajuan teknologi informasi beralih pada digital komunikasi dan/atau media sosial sebagai saluran komunikasi yang memberikan kemudahan dalam berkomunikasi tanpa dibatasi oleh ruang dan waktu. Media sosial melalui berbagai saluran yang tersedia di era digital memberikan informasi yang disampaikan semakin cepat serta interaktif. Melalui media sosial penyebaran dan/atau penyampaian informasi semakin memudahkan pendistribusian informasi.

Era digital menciptakan perubahan kondisi sosial masyarakat yang menjadikan media sosial sebagai alat komunikasi massa. Penggunaan media sosial yang sangat massif oleh masyarakat mencirikan kebebasan berkomunikasi dan menyampaikan pendapat (opini). Media sosial dapat memberikan pengaruh terhadap masyarakat luas mengingat komunikasi digital akan sangat mudah diakses dan diterima oleh masyarakat saat ini. Perkembangan teknologi komunikasi menciptakan fenomena sosial mulai berubah yang ditandai dengan adanya masyarakat internet, yang menunjukan bahwa internet di era teknologi informasi sebagai sarana penghubung dan komunikasi informasi yang dikenal dengan network society (Pratama dan Sadewo, 2015). Adanya network society menandakan masyarakat saat ini sangat dipengaruhi oleh media sosial dalam bingkai demokrasi era digital.

Kemudahan-kemudahan dalam bersosialisasi dan berkomunikasi melalui media massa yang dirasakan oleh masyarakat tentu menciptakan suatu tatanan baru didalam bermasyarakat. Oleh karena itu, adanya dinamika komunikasi masyarakat perlu diimbangi dengan tatanan hukum dalam network society agar terciptanya ketertiban serta batasan-batasan dalam menggunakan media sosial. Media sosial menjadi bagian dalam perkembangan demokrasi di era digital, sehingga masyarakat dengan mudah dan memiliki kebebasan dalam berkomunikasi, menyampaikan gagasan hingga kritik terhadap dinamika sosial maupun komunikasi antara individu dengan masyarakat, antarmasyarakat, hingga masyarakat dengan pemerintahan.

Dinamika sosial yang terjadi seiring peningkatan penggunaan media sosial oleh masyarakat tidak diimbangi dengan pemahaman dan etika dalam berkomunikasi. Seringkali masyarakat justru menggunakan media sosial untuk menyampaikan komunikasi dan informasi yang tidak etis hingga bertentangan dengan prinsip demokrasi. Dalam konsepsi Negara hukum setiap perbuatan dilandaskan pada aturan berprilaku dimasyarakat. Perilaku yang bersifat moralitas individu dalam tatanan sosial yang demokratis tidak boleh bertentangan dengan nilai-nilai individu lainnya atau nilai etika sosial. (Surahman dan Fuqoha, 2017:53) Demokrasi memberikan hak dan kebebasan bagi setiap individu untuk mengekspresikan diri, tetapi tidak dibenarkan kebebasan tersebut 
berbenturan dengan hak dan kebebasan orang lain. Oleh karena itu, kebebasan dalam penggunaan media sosial harus sesuai dengan etika dan norma yang berlaku dimasyarakat.

Salah satu bentuk penggunaan media sosial yang bertentangan dengan etika dan hukum adalah ujaran kebencian. Dalam Surat Edaran Kepala Kepolisian Negara Republik Indonesia Nomor : SE/06/X/2015 Tentang Penangan Ujaran Kebencian (Hate Speech) menjelaskan bahwa persoalan mengenai ujaran kebencian (hate speech) merupakan suatu perbuatan yang merendahkan harkat martabat manusia dan kemanusiaan. Sehingga Negara melalui kepolisian republik Indonesia perlu mengatur dan menciptakan aturan dalam rangka memelihara keamanan dan ketertiban masyarakat dari perbuatan ujaran kebencian di era digital.

Dalam implementasi penegakkan terhadap penangan ujaran kebencian, pemerintah secara bersama-sama dengan masyarakat perlu melakukan upaya pencegahan terhadap perilaku-perilaku yang dapat mendorong terciptanya uajaran kebencian. Upaya-upaya yang dapat dilakukan antara lain pertama, melakukan tindakan preventif dan kedua melakukan tindakan penegakkan hukum sesuai ketentuan hukum yang berlaku. Dalam upaya yang dilakukan pemerintah menanggulangi terjadinya ujaran kebencian yang dituangkan dalam Surat Edaran Kepala Kepolisian Negara Republik Indonesia Nomor : SE/06/X/2015 Tentang Penangan Ujaran Kebencian (Hate Speech), maka pemerintah perlu mendorong untuk memberikan pengetahuan dan pemahaman mengenai bentuk-bentuk ujaran kebencian kepada masyarakat. Selain itu, tugas pemerintah juga mendeteksi perilaku masyarakat yang dapat menimbulkan konflik dalam bentuk provokasi sebagai bagian dari early warning dan early detection.

Salah satu network society yang rawan terhadap perilaku ujaran kebencian adalah generasi muda. Oleh karena itu, pendidikan dan pemahaman terhadap perilaku ujaran kebencian harus dimulai dari generasi muda sebagai agen perubahan di masyarakat. Generasi muda, khususnya kelompok masyarakat yang masih menempuh pendidikan pada tingkat sekolah menengah atas dan/atau sederajat harus menjadi perhatian pemerintah dan masyarakat terhadap pemahaman ujaran kebencian (hate speech).Digital literasi sebagai upaya pendidikan dalam memberikan pemahaman dan pengetahuan mengenai ujaran kebencian dalam media sosial. Menurut Paul Gilster dalam bukunya yang berjudul Digital Literacy (1997), literasi digital diartikan sebagai kemampuan untuk memahami dan menggunakan informasi dalam berbagai bentuk dari berbagai sumber yang sangat luas yang diakses melalui piranti komputer. (http://gln.kemdikbud.go.id) Dari pemahaman tersebut, maka digital literasi sebagai salah satu bentuk pencegahan terhadap menyebarnya perilaku dan perbuatan tentang ujaran kebencian di media sosial.

Kegiatan pengabdian ini bertujuan untuk meningkatkan budaya literasi di era digital (digital literasi) dalam penggunaan media sosial sebagai bentuk pendidikan dan pemahaman terhadap perilaku-perilaku yang mengarah pada ujaran kebencian (hate speech) di kalangan siswa sekolah menengah atas dan/atau sederajat. Program Room of Law sebagai bentuk pengabdian masyarakat diharapkan dapat meningkatkan pengetahuan masyarakat khususnya generasi muda yang 
berfokus pada penggunaan media sosial dan ujaran kebencian (hate speech).

\section{METODE PELAKSANAAN}

Metode penelitian ini menggunakan penelitian survey (survey research) yang berusaha memaparkan deskripsi kuantitatif dari suatu populasi dengan menggunakan kuesioner atau wawancara terstruktur dalam mengumpulkan data. (Creswell, 2016:17) Dalam penelitian ini, peneliti berusaha mendeskripsikan secara kuantitatif dari beberapa kecenderungan, perilaku, atau opini dari populasi dan sampel yang diperoleh. (Creswell, 2016:208) Dari data yang dihimpun tersebut, peneliti hendak mengungkap seberapa besar perilaku generasi muda yang terpapar perilaku ujaran kebencian melalui media sosial. Kegiatan pengabdian berkonsep Participatory Learning and Action menurut Aprilia Theresia (2014) yang bertumpu pada ceramah, diskusi, curah pendapat secara interaktif dengan peserta dan/atau anggota yang terlibat dalam kegiatan dengan diakhiri aksi perlawanan terhadap perilaku ujaran kebencian. (Hasanah \& Sururi, 2018:69) Dalam kegiatan ini dilaksanakan sebagai bentuk Training of Trainer (TOT) kepada siswa sekolah sebagai agen perlawanan terhadap perilaku ujaran kebencian.

\section{HASIL DAN PEMBAHASAN}

Pelaksanaan pengabdian masyarakat melalui Program "Room of Law" dilaksanakan selama 3 (Tiga) minggu dengan kegiatan pendampingan ditiap akhir pekan yang merupakan bagian dari Program Pengabdian Masyarakat oleh Program Studi Ilmu Hukum, Universitas Serang Raya.

\section{a) Tahap pertama, survey dan analisis perilaku penggunaan media sosial.}

Dalam tahap awal pelaksanaan pengabdian yakni melaksanakan survey dan analisis terhadap penggunaan media sosial dikalangan siswa-siswa sekolah untuk menentukan potensi dan pengaruh media sosial terhadap perilaku siswa-siswa sekolah menengah atas yang meliputi jenis media sosial, pengetahuan tentang ujaran kebencian (hate speech), dan pengetahuan tentang hukum dan/atau perundang-undangan yang mengatur ujaran kebencian dan media sosial.

Berdasarkan hasil survey tingkat pengetahuan dan pemahaman terhadap penggunaan media sosial dan ancaman hukum terhadap perilaku ujaran kebencian di lingkungan sekolah menengah atas di kota serang sebagai berikut :

Tabel 1. Tingkat Pengetahuan Siswa terhadap Perilaku Ujaran Kebencian

\begin{tabular}{|c|c|c|c|}
\hline Tujuan & Indikator & $\mathrm{Ya}$ & Tida \\
\hline \multirow[t]{2}{*}{ Pengetahuan } & $\begin{array}{ll}\text { Sekolah } & \text { dapat } \\
\text { membedakan } & \text { berita } \\
\text { benar dan } & \text { berita } \\
\text { bohong di media } \\
\text { sosial }\end{array}$ & $75 \%$ & $25 \%$ \\
\hline & $\begin{array}{l}\text { sekolah mengetahui } \\
\text { peraturan hukum } \\
\text { teknologi informasi } \\
\text { (UU ITE \& Hate } \\
\text { Speech) }\end{array}$ & $20 \%$ & $80 \%$ \\
\hline \multirow[t]{2}{*}{ Sikap } & $\begin{array}{l}\text { pekolah membagikan } \\
\text { informasi melalui } \\
\text { media sosial }\end{array}$ & $90 \%$ & $10 \%$ \\
\hline & $\begin{array}{l}\begin{array}{l}\text { sekolah membuat } \\
\text { konten (status) } \\
\text { yang menyerang } \\
\text { orang lain }\end{array} \\
\end{array}$ & $30 \%$ & $70 \%$ \\
\hline Keterampilan & $\begin{array}{l}\text { sekolah membaca } \\
\text { konten } \\
\text { berita/informasi } \\
\text { yang diperoleh } \\
\text { sebelum }\end{array}$ & $70 \%$ & $30 \%$ \\
\hline
\end{tabular}




\begin{tabular}{|l|l|l|l|}
\hline & $\begin{array}{l}\text { membagikan/mengi } \\
\text { nformasikan pada } \\
\text { orang lain melalui } \\
\text { media sosial. }\end{array}$ & & \\
\hline Rata-Rata & $\mathbf{5 7 \%}$ & $\mathbf{4 3 \%}$ \\
\hline
\end{tabular}

Berdasarkan hasil survey yang dihimpun menunjukan tingkat pengetahuan dan pemahaman generasi muda setingkat sekolah menengah atas dan/atau sederajat terhadap bahaya dan potensi konflik sosial akibat penggunaan media sosial yang mengarah pada perilaku ujaran kebencian (hate speech) sangat tinggi mencapai 43\%. Sedangkan siswa-siswi yang memahami dan menggunakan media sosial dengan bijak mencapai 57\%. Dengan demikian, dapat dismpulkan pengetahuan dan pemahaman siswa akan ujaran kebencian masih sangat kurang, sehingga perlu adanya upaya pendidikan dan pelatihan bagi siswasiswi sekolah menengah atas dan/atau sederajat untuk mempelajari aturan hukum yang berlaku dalam rangka menciptakan generasi muda yang terhindar dari perilaku ujaran kebencian.

\section{b) Tahap kedua, digital literasi terhadap ujaran kebencian di media sosial.}

Dalam tahap kedua, setelah hasil survey dan analisis adalah kegiatan inti dari pengabdian, antara lain :

1) Sosialisasi program "Room of Law"

Dalam rangka menyikapi fenomena penggunaan media sosial dikalangan masyarakat yang telah menjadi bagian yang tak terpisahkan dalam era teknologi informasi. Seiring penggunaan teknologi yang semakin massif dikalangan masyarakat, pola perilaku masyarakat juga semakin dinamis dan menciptakan kondisi sosial yang bertentangan dengan nilai-nilai etis dan bertentangan dengan aturan-aturan hukum. Oleh karena itu, pemerintah mengambil sikap untuk menciptakan ketertiban dalam penggunaan media sosial dengan mengeluarkan pengaturanpengaturan mengenai penggunaan media sosial. Salah satu ketentuan yang mengatur penggunaan media sosial terhadap perilaku ujaran kebencian (hate speech) yaitu Surat Edaran Nomor : SE/06/X/2015 Tentang Penangan Ujaran Kebencian (Hate Speech).

Dalam tahap ini, tim pengabdian masyarakat bersama-sama mahasiswa melakukan sosialisasi program Room of Law dari Program Studi Ilmu Hukum Universitas Serang Raya sebagai bagian dari upaya pencegahan perilaku ujaran kebencian (hate speech) oleh siswa-siswa sekolah menengah atas. Program tersebut sebagai bentuk dukungan terhadap upaya pemerintahan melalui Kepolisian Republik Indonesia dalam menangani perilaku ujaran kebencian di kalangan masyarakat. Persoalan mengenai ujaran kebencian (hate speech) memiliki dampak merendahkan harkat martabat manusia dan kemanusiaan yang mendorong terciptanya kebencian kolektif, diskriminasi hingga kekerasan terhadap masyarakat.

Berdasarkan hal tersebut diatas, maka perlu adanya pendidikan dan pemahaman bagi masyarakat untuk memahami ujaran kebencian yang dapat berpotensi menimbulkan konflik sosial yang sangat luas, menimbulkan diskriminasi hingga kekerasan ditengah-tengah masyarakat. Oleh karena itu, program Room of Law sebagai bagian dari upaya untuk memberikan pendidikan dan pemahaman bagi masyarakat melalui kegiatan-kegiatan edukatif, sosialisasi kebijakan hukum dan teknologi, hingga pelatihan bagi masyarakat khususnya generasi muda sebagai agen perlawanan terhadap ujaran kebencian. 
Program Room of Law diselenggarakan oleh tim pengabdian yang terdiri dari dosen dan mahasiswa untuk mensosialisasikan dan melaksanakan pendidikan penggunaan media sosial dan kebijakan-kebijakan hukum terhadap masyarakat, khususnya kelompok siswa-siswa sekolah menengah atas. Melalui program ini, tim pengabdian berharap dapat memberikan pemahaman dan gambaran mengenai dampak ujaran kebencian serta menciptakan generasi muda yang bebas dari perilaku ujaran kebencian hingga menjadi agen perlawanan (agent of against) terhadap ujaran kebencian (hate speech).

\section{2) Sosialisasi hukum dan teknologi}

Kegiatan pengabdian selanjutnya setelah survey dan analisis yakni sosialisasi kebijakan hukum dan teknologi sebagai landasan serta pengaturan dalam penggunaan media sosial. Isu-isu dan/atau materi yang disampaikan terkait dengan hukum informasi dan transaksi elektronik, ujaran kebencian (hate speech). Berdasarkan informasi dan data yang dihimpun oleh Kepolisian Republik Indonesia terhadap cyber crime termasuk perliaku ujaran kebencian (hate speech) sebagai berikut :
Tabel 2. Jumlah Kasus Ujaran Kebencian Yang di Tangani Kepolisian

\begin{tabular}{|c|l|l|l|}
\hline No. & \multicolumn{1}{|c|}{$\begin{array}{c}\text { Jenis Kejahatan } \\
(\text { Cyber Crime })\end{array}$} & Tahun & Jumlah \\
\hline \multirow{2}{*}{1} & Cyber Crime & 2016 & 4.931 \\
\cline { 2 - 4 } & $\begin{array}{l}\text { Crime : Ujaran } \\
\text { Kebencian }\end{array}$ & 2016 & 1.829 \\
\hline 2 & Crime & 2017 & 5.061 \\
\cline { 2 - 4 } & $\begin{array}{l}\text { Crime : Ujaran } \\
\text { Kebencian }\end{array}$ & 2017 & 2.018 \\
\hline
\end{tabular}

Sumber : https://news.detik.com/berita/d3790973/selama-2017-polri-tangani-3325kasus-ujaran-kebencian

Berdasarkan informasi jumlah perilaku terhadap tindakan ujaran kebencian yang semakin meningkat dari tahun ke tahun menunjukan pemahaman dan pengetahuan masyarakat dalam penggunaan media sosial dan ujaran kebencian sangat lemah sampai tidak memahami dan mengetahui bahaya perilaku ujaran kebencian. Oleh karena itu, pentingnya pendidikan dan pemahaman terhadap perilaku ujaran kebencian melalui kegiatan-kegiatan sosialisasi, advokasi hingga pelatihan tentang hukum dan penggunaan teknologi.

Pentingnya hukum dalam kehidupan sosial bermasyarakat sebagai rumusan suatu pandangan mengenai perilaku atau sikap yang boleh dilakukan dan tidak boleh dilakukan. Hukum adalah peraturan-peraturan bersifat memaksa yang dibuat oleh badan-badan resmi yang berwajib, yang menentukan tingkah laku manusia dalam lingkungan masyarakat, dimana pelanggaran terhadap peraturan tersebut berdampak pada diambilnya tindakan hukum (Arrasjid, 2006:21). 
Pengaturan mengenai penggunaan teknologi informasi dalam bentuk media sosial telah diatur melalui Undang-Undang Nomor 11 Tahun 2008 Tentang Informasi dan Transaksi Elektronik. Dalam ketentuan tersebut telah diatur larangan terhadap perilaku ujaran kebencian (hate speech) yang termuat dalam Pasal 27 Ayat (3) dan (4), Pasal 28 Ayat (1) dan (2) dan Pasal 29.

Selain pengaturan melalui UndangUndang Nomor 11 Tahun 2008, diatur juga mengenai penangan perilaku ujaran kebencian (hate speech) yang dituangkan dalam Surat Edaran Kepolisian Republik Indonesia Nomor : SE/06/X/2015 Tentang Penangan Ujaran Kebencian (Hate Speech). Berdasarkan hasil survey yang dilakukan tim pengabdian terhadap siswa-siswi sekolah menengah atas di kota serang menunjukan lemahnya pengetahuan dan pemahaman hukum dalam penggunaan media sosial bahwa $80 \%$ dari siswa-siswi tingkat menengah atas tidak mengetahui potensi dan dampak yang ditimbulkan dari ujararan kebencian dan ancaman hukum yang akan diterima bagi pelaku ujaran kebencian.

Pentingnya peran kepolisian dan pemerintahan dalam menangkal dan memerangi perilaku ujaran kebencian yang dilakukan oleh masyarakat, khususnya generasi muda yang masih duduk dibangku sekolah yang belum memahami dampak dan potensi dari ujaran kebencian. Sedangkan, hampir $90 \%$ siswa-siswi sekolah membuat konten/status/informasi yang disampaikan melalui media sosial tanpa mengetahui dampak yang terjadi terhadap orang lain dan dirinya sendiri.
Dengan demikian, sosialisasi, advokasi dan pendidikan bagi siswa-siswi sekolah menengah atas sebagai salah satu solusi preventif dalam memerangi dan mencegah tindakan ujaran kebencian di tengah-tengah masyarakat yang semakin meningkat. Melalui sosialisasi kebijakan hukum dan penggunaan teknologi informasi bagi generasi muda diharapkan dapat menciptakan generasi muda yang terhindar dan membantu pemerintah memerangi perilaku ujaran kebencian. Salah satu bentuk pendidikan yang dapat diajarkan dalam penggunaan teknologi informasi pada siswa-siswi sekolah adalah digital literasi. Melalui digital literasi siswa-siswi diarahkan kepada kemampuan untuk memahami dan menggunakan teknologi informasi dalam berbagai bentuk dari berbagai sumber yang sangat luas yang diakses melalui media sosial yang digunakan oleh siswa-siswi sekolah menengah atas dan/atau sederajat.

3) Digital literasi sebagai upaya preventif terhadap perilaku hate speech.

Penggunaan media sosial di era digital saat ini sudah menjadi bagian dari kehidupan masyarakat baik di kota besar hingga masyarakat di desa kecil. Oleh karena itu, media sosial tidak dapat dihindari tetapi perlu diatur dalam penggunaannya sehingga tidak merugikan masyarakat yang lain. Media sosial sebagai salah satu sarana efektif dan efisien dalam berkomunikasi dan menyampaikan informasi kepada pihak lainnya. Dengan teknologi informasi yang memberikan kemudahan dalam berkomunikasi, media sosial menjadi suatu sarana/media untuk bersosialisasi antara satu orang dengan orang lainnya tanpa dibatasi ruang dan waktu. 
Sebagai bagian sarana bersosialisasi masyarakat, media sosial memiliki dampak perubahan pada sikap individu dan/atau masyarakat atas informasi yang diterima. Oleh karena itu, pentingnya memahami penggunaan media sosial dalam berkomunikasi massa sehingga tidak menimbulkan persoalan ditengah-tengah masyarakat. Perubahan perilaku sosial yang diakibatkan dari penerimaan dan/atau penolakan informasi yang diperoleh dari media sosial akan berpotensi timbulnya perpecahan dalam pergaulan bermasyarakat.

Dengan demikian, digital literasi bagi masyarakat khususnya generasi muda menjadi bagian dari upaya pendidikan terhadap penggunaan media sosial secara berkelanjutan. Dalam tahap kegiatan pengabdian ini yaitu mengadakan pelatihan kepada siswa-siswa sekolah untuk menjadi agent of against di lingkungan sekolah menengah atas di kota Serang. Langkah-langkah spesifik yang diperlukan dalam pendidikan dan pelatihan menangkal perilaku ujaran kebencian antara lain :

\section{a) Seminar Hukum Teknologi Informasi dan Gerakan anti-Hoax}

Seminar dilakukan guna memberikan pemahaman kepada siswa-siswi sekolah terhadap penggunaan media sosial, potensi dan dampak yang diakibatkan oleh informasi dari media sosial, ancaman hukum terhadap perilaku ujaran kebencian (hate speech) melalui media sosial. Dari hasil sosialisasi dan seminar diharapkan para generasi muda khususnya siswa-siswi sekolah dapat menggunakan media sosial secara bijak sehingga terhindar dari perilaku ujaran kebencian. b) Pelatihan Training of Train (TOT) Agent of Against Hate Speech

Kegiatan terakhir dari program Room of Law adalah menyelenggarakan pelatihan kepada siswa-siswi sekolah untuk menjadi agen dalam memerangi (agent of against) terhadap perilaku ujaran kebencian (hate speech). Pelatihan tersebut dilakukan guna membekali siswa-siswi sekolah untuk menyebarkan bahaya dan ancaman perilaku ujaran kebencian melalui media sosial kepada masyarakat luas. Sehingga upaya preventif dalam melawan ujaran kebencian dapat dilakukan seluruh masyarakat khususnya generasi muda.

\section{PENUTUP}

Dari kegiatan yang telah dilaksanakan dapat disimpulkan bahwa perilaku ujaran kebencian ditingkat sekolah menengah atas dan/atau sederajat sangat tinggi mencapai $43 \%$ yang berarti para siswa-siswi pengguna media sosial tidak menggunakan teknologi informasi secara bijak. Sedangkan tingkat siswa-sisiwi yang memahami dan menggunakan teknologi dengan benar hanya sebesar $57 \%$, yang berarti tingkat pemahaman dan pengetahuan terhadap penggunaan media sosial masih rendah yang berpotensi meningkatkan perilaku ujaran kebencian ditengah-tengah masyarakat. Selain itu, siswa-sisiwi sekolah tidak mengetahui ancaman hukum yang ditimbulkan dari perbuatan ujaran kebencian dimana hasil survey menunjukan $80 \%$ siswa sekolah menengah atas di kota serang tidak mengetahui ancaman hukum yang diatur oleh pemerintah.

Digital literasi terhadap siswa-siswi sekolah sebagai salah satu upaya pencegahan atau tindakan preventif untuk memerangi perilaku ujaran kebencian (hate speech). 
Dengan berbagai kegiatan yang dilakukan dapat memberikan pemahaman dan pendidikan pada siswa-siswi sekolah menengah atas akan bahaya ujaran kebencian. Selain itu, pendidikan dan pelatihan untuk memerangi ujaran kebencian menjadi strategi dalam memerangi ujarang kebencian secara luas dengan menciptakan agent of against hate speech.

\section{REFERENSI}

\section{Buku dan Jurnal}

Arrasjid, Chainur. (2006). Dasar-Dasar Ilmu Hukum. Ed. 1. Cet. 4. Jakarta : Sinar Grafika.

Creswell, John W. (2016). Research Design : Pendekatan Metode Kualitatif, Kuantitatif dan Campuran. Cetakan I. Yogyakarta : Pustaka Pelajar.

Hasanah, B., \& Sururi, A. (2018). Peningkatan Kapasitas Aparatur Pemerintahan Desa dan Masyarakat Melalui Pelatihan Administrasi Pemerintahan di Desa Sukamenak Kecamatan Cikeusal Kabupaten Serang. Wikrama Parahita: Jurnal Pengabdian Masyarakat, 2(2), 6874. Retrieved : http://dx.doi.org/10.30656/ jpmwp.v2i2.606

Pratama, Harrys Nanda dan FX Sri Sadewo. Social Networking System Sebagai Public Sphere Politik Era Postdemokrasi Kampanye Pilpres 2014. Jurnal Paradigma, 3 (1), 2015. Retrieved: https://jurnalmahasiswa.unesa.ac.id/index. php/paradigma/article/viewFile/10459/101 $\underline{87}$
Surahman, S., \& Fuqoha, F. (2017). Mekanisme Penyelesaian Pelanggaran Kode Etik Jurnalistik Pada Dewan Pers di Kota Serang. LONTAR: Jurnal Ilmu Komunikasi, 5(2). Retrieved : http://dx.doi. org/10.30656/lontar.v5i2.491

\section{Peraturan Perundang-Undangan :}

Undang-Undang No. 11 Tahun 2008 Tentang Informasi dan Transaksi Elektronik.

Surat Edaran Kepala Kepolisian Negara Republik Indonesia Nomor : SE/06/X/2015 Tentang Penangan Ujaran Kebencian (Hate Speech).

\section{Website :}

https://news.detik.com/berita/d-3790973/ selama-2017-polri-tangani-3325-kasusujaran-kebencian diakses 26 Januari 2019

http://gln.kemdikbud.go.id/glnsite/bukuliterasi-digital/ diakses pada 26 Januari 2019. 